\title{
KOZMA GÁBOR: PLACE MARKETING
}

\author{
(Kossuth Egyetem Kiadó, Debrecen, 2006, 160 o.)
}

\section{HEGYI FATIME BARBARA}

A terület- és településmarketing irodalma számos jelentös nemzetközi publikációval bír, míg csekély azon hazai könyvek száma, amelyek egy átfogó képet nyújtanak erröl a szakterületről. Kozma Gábor három kiadást megélt „Terület és Településmarketing" címü jegyzete 2006-ban angolul is elérhetővé vált a hallgatók, kutatók, illetve érdeklődők számára.

A témakör fontossága az önkormányzati rendszer kialakulásában rejlik, hiszen a decentralizációs folyamat révén a magyarországi települések jelentös autonómiára tettek szert, amely nagyobb teret biztosított önszervezödö tevékenységeik, illetve fejlesztési elképzeléseik számára. Ezáltal, a városok kezébe került a lehetőség arra, hogy forrásokért, funkciókért, befektetésekért versengjenek. A terület- és településmarketing egy eszközrendszert kínál a város vezetése számára ahhoz, hogy a település sikeresen legyen képes versenyezni mindezekért a forrásokért, funkciókért. A jegyzet aktualitása abban rejlik, hogy Magyarországon az önkormányzatok marketing tevékenysége csak most van kialakulóban. Az alapos elméleti összefoglalón túl részletes gyakorlati útmutatóval is szolgál.

A jegyzet sokat segít az olvasónak abban, hogy elhelyezze a helymarketing tevékenységét a marketing tudományában, továbbá szemlélteti, hogy milyen kapcsolat áll fenn a hagyományos termékek marketingje, illetve a terület- és településmarketing között. Egy területi egység, azaz egy hely marketing tevékenységét takarja a terület- és településmarketing tudománya, magába foglalva az ország-, város-, régió- és községek marketingtevékenységét is.

A szerzö taglalja az önkormányzati marketing tevékenység kialakulásának okait, melyek között a legjelentősebb, hogy a helyi önkormányzatok egyre nagyobb figyelmet kívántak szentelni a településüknek, valamint a településükön zajló változásoknak, kölcsönhatásoknak. A terület- és településmarketing által oly módon lettek képesek az önkormányzatok befolyásolni, illetve irányítani a településen történö folyamatokat, hogy azok elönyösek legyenek mind a település, mind az önkormányzati vezetés számára. Az önkormányzati vezetöknek ezért egy vállalkozói szemléletet kellett elsajátítaniuk ahhoz, hogy a településük versenyképessé, így sikeressé válhasson.

Nagyon pontosan kiemeli és részletezi a jegyzet, hogy a terület- és településmarketing többról szól, mint reklám- és kommunikációs tevékenység. A szerző értelmezése szerint, a terület- és településmarketing egy komplex vezetési szemlélet, egy stratégia, illetve a stratégiát megvalósító eszközrendszer tudománya. Célja, a településen élö csoportok életszínvonalának fenntartása, illetve növelése, amely csakis a település versenyképességével érhető el. A terület sikerét a növekvő jövedelmek és 
a növekvö foglalkoztatottság jelentik, illetve a település alkalmazkodóképessége az állandó gazdasági, társadalmi változásokhoz. Továbbá, a sikeres település egy olyan helyet takar, ahol magas a szolgáltató szektorok aránya, ahol erős az innovációs képesség, a középosztály, valamint jelentős külkapcsolatokkal rendelkezik.

A hely egy termékként értelmezhetỏ és értelmezendő, amely természetesen sokban eltér a hagyományos fogyasztói termékektöl, mégis céljaikban megegyeznek; a végső szándék a hely eladása a piacon. Az eladásnak - a hely viszonylatában is csakis akkor van értelme, hogyha piaccal rendelkezik a termék, vagyis van rá megfelelő kereslet. Ezért, a termék kialakításánál fontos a célcsoportok meghatározása; így a fogyasztók igényeinek alapos és körültekintő értelmezése és elemzése. A helymarketing esetében a fogyasztókat a lakosság, a gazdasági szereplők, intézmények, és turisták jelentik, amely csoportok minden esetben tovább bonthatóak a jelenlegi, illetve a potenciális fogyasztók csoportjaira.

A fogyasztói igényeknek való megfelelés azért kiemelkedö fontosságú a helymarketing esetében, mert csakis így képes a hely sikeresen versenyezni a bevezetöben említett befektetésekért, forrásokért vagy akár a lakosság bizonyos csoportjaiért. Versenyképességgel biztosítható a jólét, illetve általa valósítható meg a gazdasági, társadalmi, kulturális fejlödés a településen. A tökeképesség, az adaptabilitás, illetve az exportképesség teszi elérhetôvé a területek számára a jövedelemtermelést, így a versenyképesség növelését. Mindez viszont nem valósulhat meg a megfelelö technikai és társadalmi tudás nélkül, így a versenyképesség alapfeltétele a minél szélesebb és alaposabb tudásbázis hozzárendelése a helyi gazdasági folyamatokhoz. A verseny a városok között is egy dinamikus folyamat, amely igényli az állandó alkalmazkodóképességet a település részéről. Mégis, a végeredmény nem egy zéróơsszegü játék, hiszen itt az egyik település nem csupán a másik javára nyerhet, hanem egyidejüleg több településen is történhet fejlődés.

A jegyzet három fö részre osztja a helymarketing folyamatát; elemzésre, termékfejlesztésre és kommunikációra. Így a területi egység fejlesztését minden esetben egy alapos elméleti elemzésnek kell megelöznie. A termékfejlesztést követően hatékonyan kommunikálni kell a termék létezését, tulajdonságait és adottságait a célcsoportok felé. Az elemzés jelenti mindazokat a tevékenységeket, amelyek megalapozzák a fejlesztést és a kommunikációt. Az elméleti vizsgálatoknak egy SWOT analízissel kell kezdödniük, amely során a településnek fel kell mérnie a saját gyengeségeit, illetve erösségeit, majd fel kell térképeznie azokat a területeket, ahol lehetỏségei volnának a fejlödésre, illetve a felmerülö veszélyeket. Ez az elemzés kulcsfontosságú a stratégia és jövőkép megfogalmazása szempontjából. A SWOT analízisre alapozva ki kell választani a marketing politikát, majd meg kell határozni azokat a célcsoportokat, amelyeket fogyasztásra kíván a település ösztönözni. A célcsoportok definiálása mellett meg kell határozni a fejlesztési prioritásokat is.

A piac szegmentáció során azt a fogyasztói csoportot kell kiválasztani, amely számára a terméket, vagyis a települést vonzóvá szeretné tenni a város vezetése. Legfontosabb eleme a piac felosztásának a célcsoportok termékhez való viszonyának a vizsgálata, hiszen minden csoportnak más-más előnyöket jelentenek az egyes pénz- 
ügyi-, időbeli-, pszichikai ösztönzők. Ezért fontos megkülönböztetni a már említett jelenlegi, illetve a potenciális felhasználók körét. Mivel a helymarketing célja az ösztönzés, ezért míg a potenciális fogyasztókat felhasználókká kell formálnia, addig a jelenlegi felhasználókat további fogyasztásra kell ösztönöznie.

A fejlesztési prioritások kialakításának alapjait mindezek az elemzések adják. A terület erösségeire támaszkodva kell megszabnia azokat az irányokat, amelyek a fejlesztések fö törekvéseit adják.

A helymarketing estében a termékfejlesztésnek számtalan izgalmas és innovatív módozata lehetséges. A végső cél a vonzó település kialakítása. A jegyzet a termékfejlesztésnek négy nagy kategóriáját tárgyalja; az infrastruktúrafejlesztést, az intézményi háttér megteremtését, a rendezvényszervezést és az építészetet, mint helymarketing eszközöket. Az infrastruktúra fejlesztése megvalósulhat szellemi és tárgyi infrastruktúrafejlesztésben is. Az intézményi háttér megteremtése során, az önkormányzatnak a saját keretein belül kell kialakítania azokat a szervezeti egységeket, amelyek biztosítják a fejlesztési célok megvalósulását, illetve hatékony együttmüködéseket kell kiépítenie az állami, magán és non-profit szervezetekkel. A különböző rendezvények olyan rugalmas kikapcsolódási lehetőségeket nyújtanak különféle fogyasztók számára, amelyekre egyrészröl növekvő társadalmi igény merül fel a társadalmakban, másrészrôl népszerüsítik a települést, illetve a település egyes szolgáltatásait. Az építészettel egy egyedi arculat alakítható ki, amellyel megkülönböztethetővé válik a település a versenytársaitól.

A kommunikációs tevékenység során meg kell határozni az üzenet tartalmát, amit el kíván a település juttatni a célfogyasztókhoz. Ennek az üzenetnek tartalmaznia kell azokat az előnyöket, amelyek meggyözik, illetve fogyasztásra ösztönzik a célcsoportokat.

A rövid összefoglalásból is kitủnik, hogy olyan jegyzetet vesz a kezébe az érdeklődö, mikor Kozma Gábor helymarketingröl szóló jegyzetét olvassa, amely alapjául szolgálhat további kutatásoknak és olvasmányoknak. Egy jól strukturált, átfogó, alapos elemzés részletes bibliográfiával. Megragadja a terület- és településmarketing lényegét, így kiemeli, hogy a helymarketing több mint elhagyatott területek újjáépítését segitő önkormányzati tevékenység. A helymarketing alkalmazása hozzásegíti a települést ahhoz, hogy sikeressé váljon, így hozzájárul ahhoz, hogy egy olyan település formálódjon, amely innovatív, alkalmazkodó, illetve ahol a fejlesztések a fogyasztók jóletét szolgálják. 
Tér és Társadalom 20. évf. 2006/2. 143-156. p.

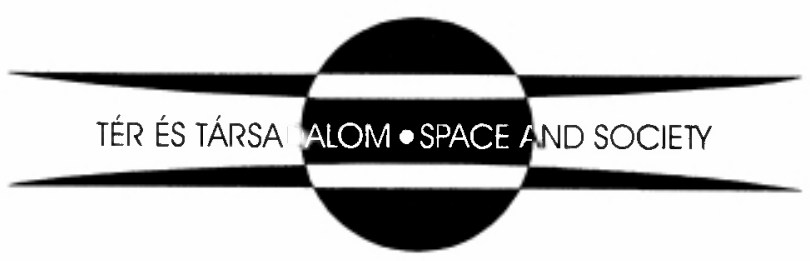

